\title{
SELF-CONCEPT AND ANXIETY OF POTENTIAL SLOVAK LEADERS
}

\author{
Lenka Ďuricová, \& Beata Žitniaková Gurgová \\ Department of Psychology, Faculty of Education, Matej Bel University in Banska Bystrica (Slovakia)
}

\begin{abstract}
Purpose: The purpose of this paper is to examine self-concept and anxiety of the Slovak university students as future leaders. The positive self-concept and emotional stability are considered important characteristics of effective leaders.

Research method: Our research sample consisted of 199 students (mean age=20.04; SD=1.58;) of Matej Bel University (field of study: management and education). The available and intentional sampling was used. The research tools were: State-trait anxiety inventory (Slovak version: Müllner, Ruisel, \& Farkaš, 1980) and Piers-Harris self-concept scale for children and adolescent 2 (Czech version, 2015; translation to Slovak: Duricová \& Ladnová, 2018). Reliability (inner consistency) of measured variables was acceptable (Cronbach alpha from .558 to .902 for state and trait anxiety and all self-concept dimensions. The correlation research study was conducted.

Results: Our findings prove negative moderate or strong statistically significant correlations between all self-concept dimensions and state and trait anxiety (from -.262 to $-.567 ; \mathrm{p}=.001$ ). There has been proved strong significant relation between the total self-concept and state and trait anxiety $(-.556 ;-.684 ; \mathrm{p}=0.001)$. Research limitations: Data were self-reported. The sample size.

Value: This paper presents the contribution to the research of relevant personal factors of tomorrow's leaders in education and economics in Slovakia.

The paper was supported by The Slovak Research and Development Agency: APVV 17-0557 project.
\end{abstract}

Keywords: leadership, trait anxiety, state anxiety, self-concept.

\section{Introduction}

According to Bass and Bass (2009), the leadership literature has not shed light on a concerted definition or its constitution. Yukl (2009, p.13) defines leadership as "the process of influencing others to understand and agree about what needs to be done and how to do it, and the process of facilitating individual and collective efforts to accomplish shared objectives." Simplifying the definition, leadership is the ability to influence a group towards the achievement of goals. Leadership is a demanding, unrelenting job with enormous pressures and grave responsibilities. Kirkpatrick and Locke (1991) believes it takes a special kind of person to master the challenges of opportunity.

One of the earliest approaches to understanding leadership was the trait approach emphasizing on the personality of leaders. Contemporary research suggests the importance of five personality traits to determine leader's effectiveness and the leadership style (Judge \& Bono, 2000; Judge et al., 2002; Anderson, 2006; Hassan et al., 2016).

The study of leader traits has a long history. There is constantly reported self-confidence among leader's core traits associated with emotional stability. Every major review of the leadership literature lists self-confidence as an essential characteristic for effective leadership (Bass, 1990; Locke, 1991; Yukl, 2009; House \& Aditya, 1997). There are many reasons why a leader needs self-confidence (Kirkpatrick \& Locke, 1991; Northouse, 2016; Axelrod, 2017; Holsinger, 2018). A great deal of information must be gathered and processed. A constant series of problems must be solved and decisions made. A person riddled with self-doubt would never be able to take the necessary actions nor command the respect of others. Self-confidence plays an important role in decision-making and in gaining others' trust. They have a positive attitude about themselves and are able to press ahead with the belief that, if and when they make a wrong decision, any setback can be overcome. Self-confidence helps effective leaders remain even-tempered. Emotional stability is especially important when resolving interpersonal conflicts and when representing the organization. Leaders who derail are less able to handle pressure and more prone to moodiness, angry outbursts, and inconsistent behaviour, which undermines their interpersonal relationships with subordinates, peers, and superiors. On the contrary, the successful leaders are calm, confident, and predictable even during crisis. Emotional stability operates as relevant variable even in profile approach to 
effective leadership (Parr et al., 2016). Emotional stability is also in positive relationship to up-to-date network leadership performance (Grift, 2016).

The aim of our research study was to examine self-concept and anxiety of the Slovak university students as future leaders. They represent tomorrow's leaders in education and economics in Slovakia. Our objective was to verify the relationship between student's positive self-concept (perceived as the assumption of his future self-confidence) and his state and trait anxiety (the lack of emotional stability). Considering listed empirical research we state these hypothesis:

H1: There is statistically significant negative correlation between student's state anxiety and their total self-concept.

H2: There is statistically significant negative correlation between student's trait anxiety and their total self-concept.

\section{Methods}

The research was carried out in Matej Bel University in Banska Bystrica, Slovakia. Our research sample consisted of 199 university students (mean age $=20.04 ; \mathrm{SD}=1.58$ ). The available and intentional sampling was used (late adolescence and field of university study: management or education). The research was realized anonymously by the means of questionnaire set:

1. The Piers-Harris Children and Adolescent's Self-Concept Scale 2 (Czech version: Obereignerů et al., 2015; translation to Slovak: Duricová \& Ladnová, 2018). Except of total score (TOT), the questionnaire includes 6 subscales evaluating specific domains of self-concept $(\alpha=$ Cronbach alpha): behavioural adjustment (BEH; $\alpha=.647$ ), intellectual and school status (INT; $\alpha=0.558$ ), physical appearance (PHY; $\alpha=.696$ ), freedom from anxiety (FRE; $\alpha=.721$ ), popularity (POP; $\alpha=.626$ ), happiness and satisfaction (HAP; $\alpha=.762$ ).

2. State-trait anxiety inventory (Slovak version: Müllner, Ruisel, \& Farkaš, 1980), measures state anxiety (the current level of anxiety; $\alpha=.902$ ) and trait anxiety (anxiety as an individual disposition; $\alpha=.899)$.

Obtained data were processed by the statistical program SPSS using the procedures of descriptive and inductive statistics.

\section{Results}

Since our variables didn't fulfil the condition of normal distribution, non-parametric procedure was used to analyse the data. Based on the results (Table 1), we can state that there are strong negative statistically significant relations between the total self-concept and state and trait anxiety. More detailed analysis brought negative moderate statistically significant correlations between all self-concept dimensions and state and trait anxiety. Especially strong is the negative correlation between trait anxiety and freedom from anxiety and happiness and satisfaction.

Table 1. Correlation analysis (Spearman) of student's anxiety and self-concept $(N=199)$.

\begin{tabular}{|c|c|c|c|c|c|c|c|c|c|}
\hline Variables & 1 & 2 & 3 & 4 & 5 & 6 & 7 & 8 & 9 \\
\hline M (mean) & 11.75 & 10.42 & 7.74 & 6.94 & 7.87 & 8.29 & 41.31 & 39.45 & 46.11 \\
\hline $\begin{array}{l}\text { SD } \\
\text { (stand.dev.) }\end{array}$ & 2.06 & 2.45 & 2.36 & 2.49 & 2.17 & 2.04 & 8.03 & 10.24 & 9.62 \\
\hline 1. $\mathrm{BEH}$ & & $.360^{* * *}$ & .115 & $.191^{* *}$ & $.152^{*}$ & $.220^{* * *}$ & $.501^{* *}$ & $-.320^{* *}$ & $-.262^{* * *}$ \\
\hline CI $(95 \%)$ & & $.23-.49$ & $-.02-.25$ & $.07-.32$ & $.02-.03$ & $.08-.36$ & $.40-.60$ & $-.45-.18$ & $-.39-.13$ \\
\hline 2. INT & & & $.406^{* *}$ & $.185^{* *}$ & $.160^{*}$ & $.306^{* *}$ & $.587^{* *}$ & $-.337^{* *}$ & $-.322^{* *}$ \\
\hline CI $(95 \%)$ & & & $.29-.52$ & $.05-.32$ & $.03-.29$ & $.18-.44$ & $.49-.67$ & $-.46-.20$ & $-.44-.18$ \\
\hline 3. PHY & & & & $.441^{* *}$ & $.466^{* *}$ & $.721^{* *}$ & $.708^{* *}$ & $-.321^{* *}$ & $-.475^{* *}$ \\
\hline CI $(95 \%)$ & & & & $.32-.55$ & $.35-.57$ & $.64-.79$ & $.63-.78$ & $-.45-.19$ & $-.58-.36$ \\
\hline 4. FRE & & & & & $.480^{* *}$ & $.511^{* *}$ & $.716^{* *}$ & $-.485^{* *}$ & $-.668^{* *}$ \\
\hline$C I \rho(95 \%)$ & & & & & $.35-.59$ & $.39-.62$ & $.64-.79$ & $-.59-.79$ & $-.75-58$ \\
\hline 5. POP & & & & & & $.383^{* *}$ & $.625^{* *}$ & $-.334^{* *}$ & $-.387^{* * *}$ \\
\hline$C I \rho(95 \%)$ & & & & & & $.25-.51$ & $.52-.71$ & $-.46-.20$ & $-.50-.25$ \\
\hline 6. HAP & & & & & & & $.727^{* *}$ & $-.452^{* * *}$ & $-.567^{* *}$ \\
\hline CI $(95 \%)$ & & & & & & & $.64-.80$ & $-.57-.32$ & $-.67-.45$ \\
\hline 7. TOT & & & & & & & & $-.556^{* * *}$ & $-.684^{* * *}$ \\
\hline CI $(95 \%)$ & & & & & & & & $-.65-.45$ & $-.75-.60$ \\
\hline 8. State anxiety & & & & & & & & & $.702^{* *}$ \\
\hline$C I \rho(95 \%)$ & & & & & & & & & $.62-.76$ \\
\hline 9. Trait anxiety & & & & & & & & & \\
\hline
\end{tabular}




\section{Conclusion}

Our results confirm strong negative correlation between student's self-concept and his/her level of anxiety. The stronger positive self-concept the lower the anxiety is. This finding corresponds with previous empirical research (Judge et al., 1998; Judge \& Bono, 2000; Judge et al., 2002). Trait anxiety has direct association to a leader health status (Lindorff, 1995). The most common drugs used by managers are for treating depression, insomnia and anxiety (St-Hilaire \& Gilbert, 2018). Mortensen (2014) also deals with disastrous outcomes of leader's chronic anxiety. In terms of prevention, it is then desirable to develop student's positive self-concept during the study.

By longitudinal study Benson (2018) confirmed that a leader's self-confidence can be developed in youth in a leadership training program and that a leader's effectiveness and leader's self-confidence will persist over time to become permanent. Hollenbeck and Hall (2004) found that education enhances an individual's level of self-efficacy by providing knowledge and skills. Here we can see an opportunity in developing new study programs for future teachers and economists as future leaders.

\section{References}

Anderson, J. A. (2006). Leadership, personality and effectiveness. The Journal of Socio-Economics, 35 , $1078-1091$.

Axelrod, R. H. (2017). Leadership and Self-Confidence. In J. Marques, S. Dhiman (Eds.) Leadership Today: Practices for Personal and Professional Performance (297-313). Switzerland: Springer International Publishing.

Bass, B.M. (1990). Stogdill's handbook of leadership. New York: Free Press.

Bass, B. M., \& Bass, R. (2009). The Bass handbook of leadership: Theory, research, and managerial applications. New York,NY: Simon and Schuster.

Benson, L. (2018). Permanency of Leader Self-Confidence Development: A Longitudinal Comparative Analysis. PEOPLE: International Journal of Social Sciences, 4(2), 906-931.

Duricová, L. \& Ladnová, Z. (2018). Perceived parenting style and self-concept of Slovak pubescent youth. The New Educational Review 52 (2), 55-65.

Grift, M. (2016). The role of emotional stability, extraversion and the motivation to affiliate on network leadership performance. Master thesis: Utrecht University.

Hassan, H., Asad, S. \& Hoshino, Y. (2016). Determinants of leadership style in big five personality dimensions. Universal Journal of Management, 4 (4), 161-179.

Hollenbeck, G.P. \& Hall, D. (2004). Self-Confidence and Leader Performance. Organizational Dynamics, 33 (3). 254-269.

Holsinger, J.W. (2018). Traits, skills, and styles of leadership. In J.W Holsinger \& E.L. Carlton, Leadership for Public Health: Theory and Practice. Health Administration Press.

House, R.J., \& Aditya, R.N. (1997). The social scientific study of leadership: Quo vadis? Journal of Management, 23, 409-473.

Judge, T.A., Erez, A. \& Bono, J.E. (1998). The power of being positive: the relation between positive self-concept and job performance. Human Performance, 11 (2-3), 167-187.

Judge, T. A., \& Bono, J. E. (2000). Five-factor model of personality and transformational leadership. Journal of applied psychology, 85, 751-765.

Judge, T. A., Bono, J. E., Ilies, R., \& Gerhardt, M. W. (2002). Personality and leadership: a qualitative and quantitative review. Journal of applied psychology, 87, 765-780.

Kirkpatrick, S.A. \& Locke, E.A. (1991). Leadership: do traits matter? Academy of Management Executive, $5(2), 48-60$.

Locke, E.A. (1991). The essence of leadership: The four keys to leading successfully. New York: Lexington Books

Lindorff, M. (1995). Predictors of symptom increase among managers - the role of environmental, personal and situational characteristics. Stres Medicine, 11(1), $41-50$

Mortensen, R. (2014). Anxiety, work and coping. The Psychologist-Manager Journal, 17 (3), 178-181

Müllner, J., Ruisel, I. \& Farkaš, G. (1980). Dotazník na meranie úzkosti a úzkostlivosti. Bratislava: Psychodiagnostické a didaktické testy.

Northouse, P. G. 2016. Leadership: Theory and Practice, 7th ed. Los Angeles: Sage.

Parr, A. D., Lanza, S. T., \& Bernthal, P. (2016). Personality Profiles of Effective Leadership Performance in Assessment Centres. Human performance, 29(2), 143-157.

St-Hilaire, F. \& Gilbert, M.H. (2018) What the leaders need to know about managers' mental health? Organizational Dynamics, 2018, https://doi.org/10.1016/j.orgdyn.2018.11.002

Yukl, G. (2009). Leadership in Organizations. New Delhi: Dorling Kindersley. 